\title{
Relationship between perceived stigma and depressive symptomatology in women who legally interrupt pregnancy in Mexico City
}

\author{
Midiam Moreno López, 'Karla Flores Celis, ' Catalina González-Forteza, ${ }^{1}$ María Teresa Saltijeral, ' Raffaela Schiavon, ${ }^{2}$ \\ María Elena Collado, ${ }^{2}$ Olivia Ortiz, ${ }^{3}$ Luciana Ramos Lira'
}



Dirección de Investigaciones Epidemiológicas y Psicosociales, Instituto Nacional de Psiquiatría Ramón de la Fuente Muñiz, Ciudad de México, México.

2 International Projects Assistance Service (lpas), México.

3 Acompañamiento Después de un Aborto Seguro (ADAS), México.

\section{Correspondence:}

Luciana Ramos Lira

Dirección de Investigaciones Epidemiológicas y Psicosociales. Instituto Nacional de Psiquiatría Ramón de la Fuente Muñiz.

Calz. México-Xochimilco 101, San Lorenzo Huipulco, Tlalpan, 14370,

Ciudad de México.

Phone: 554160 - 5186

Email: ramos|@imp.edu.mx

Received: 6 November 2018

Accepted: 8 January 2019

Citation:

Moreno López, M., Flores Celis, K., González-Forteza, C., Saltijeral, M. T., Schiavon, R., Collado, M. E. Ortiz, O., Ramos Lira, L. (2019). Relationship between perceived stigma and depressive symptomatology in women who legally interrupted pregnancy in Mexico City. Salud Mental, 42(1), 25-32.

DOI: $10.17711 /$ SM.0185-3325.2019.004

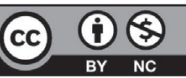

\begin{abstract}
Introduction. Although the international literature suggests that women who interrupt a pregnancy in safe conditions do not develop mental health problems, it continues to be a highly stigmatized issue by broad social sectors. It is therefore not surprising that abortion stigma is one of the main factors associated with the presence of mental health problems in women who abort voluntarily. This study explores the association between perceived abortion stigma and depressive symptomatology. Method. In a non-probabilistic convenience sample, 114 users of a Legal Interruption of Pregnancy Clinic in Mexico City were interviewed with a structured instrument. Results. Respondents obtained low scores of internalized stigma and reported feeling confident that they had made the right decision to terminate their pregnancies, and at peace with themselves. The highest scores for abortion stigma were reported in the group with high depressive symptomatology, with no statistically significant differences being observed due to the sociodemographic characteristics explored. The participants in this study were more concerned about what others might think about their decision to terminate a pregnancy and about how their abortion might affect their relationship with them. Discussion and conclusion. These concerns highlight the need to reduce the negative social stigma surrounding abortion and to provide interventions in the same direction among women who interrupt a pregnancy legally in order to reduce the risk of mental health problems such as depression.
\end{abstract}

Keywords: Induced abortion, abortion stigma, depressive symptoms, pregnancy interruption.

\section{RESUMEN}

Introducción. A pesar de que la literatura internacional señala que las mujeres que interrumpen sus embarazos en condiciones seguras no desarrollan problemas de salud mental, sigue siendo una situación altamente estigmatizada por amplios sectores sociales. Por ello, no es de sorprender que el estigma por abortar sea uno de los principales factores asociados con la presencia de malestares en la salud mental de algunas mujeres que abortan voluntariamente. Este trabajo explora la asociación entre el estigma percibido por abortar y la sintomatología depresiva. Método. En una muestra no probabilística y por conveniencia, 114 usuarias de una Clínica de Interrupción Legal del Embarazo de la Ciudad de México fueron entrevistadas con un instrumento estructurado. Resultados. Las participantes obtuvieron bajas puntuaciones de estigma internalizado, reportaron sentirse seguras y en paz con ellas mismas por haber decidido interrumpir sus embarazos. Las puntuaciones más altas de estigma por abortar se reportaron en el grupo con sintomatología depresiva elevada, sin que existieran diferencias significativas por las características sociodemográficas exploradas. Las participantes en este estudio estaban más preocupadas por lo que otros pudieran pensar por su decisión de interrumpir su embarazo y por cómo podría afectar el aborto su relación con estas personas. Discusión y conclusión. Estas preocupaciones evidencian la necesidad de disminuir el estigma social negativo que rodea al aborto y plantear intervenciones que actúen en el mismo sentido entre las mujeres que interrumpen legalmente un embarazo para disminuir el riesgo de presentar problemas de salud mental como la depresión.

Palabras clave: Aborto inducido, estigma, síntomas depresivos, interrupción del embarazo. 


\section{INTRODUCTION}

Voluntary interruption of pregnancy is a practice rejected by certain social sectors and health professionals, which cites both ethical and moral reasons and the possible effects on the physical and mental health of women who carry it out (Lerner, Guillaume, \& Melgar 2016). However, the results of systematic reviews show that there is no direct association between induced abortion in safe and legal conditions and the presence of health problems, specifically those involving mental health (Vignetta et al., 2008; Major et al., 2009; Robinson et al., 2009; National Collaborating Center for Mental Health, 2011; Russo, 2014). In fact, evidence has shown that the negative consequences on mental health appear to be more related to other factors, such as abortion stigma (Steinberg et al., 2016).

Kumar, Hessini, \& Mitchell (2009) conceptualize abortion stigma as a "negative attribute ascribed to women seeking to terminate a pregnancy [that] marks them internally or externally as inferior to ideals of womanhood." They argue that this stigma is extremely powerful because women who abort challenge three basic cultural beliefs held by broad social groups about the "nature" of being a woman: 1. a woman only has sex to procreate; 2 . motherhood is inevitable; 3 . a woman is naturally vulnerable. Cockrill \& Hessini (2014) posit that this stigma comprises at least two dimensions: the internalized and the perceived social dimension. The first refers to the negative point of view women who abort have about themselves, which creates feelings of guilt and shame and other emotions that produce distress and concealment. The second refers to the individual perceptions women have about the attitudes of others and therefore about the perceived risk of being judged, rejected, or discriminated against for having an abortion.

According to O'Donnell et al. (2018), by interrupting a pregnancy, women access a socially constructed, stigmatized identity, which can lead them to experience effects on their emotional well-being. Their results also show that self-stigmatization due to abortion predicts anxious and depressive distress, including internalized shame and deliberate isolation from other people. It should be mentioned that induced abortion is the result of a decision made after days or weeks of consideration. Since this process can be difficult, its psychological consequences would therefore appear to be more related to the social, moral, and psychological context in which it occurs than to the medical procedure itself (Broen, Moum, Bødtker, \& Ekeberg, 2005). Feelings of guilt and shame may be exacerbated because they are related to beliefs such as considering abortion a sin (LeTourneu \& Tyson, 2016). This can lead women to have a more negative view of the event (Rocca et al., 2015) and accordingly may increase their emotional distress if they do in fact have an abortion (Kimport, Foster, \& Weitz, 2011).
There are also variations in the way this stigma is expressed in various social groups. For example, Hispanic women in the United States perceive increased stigma on the part of friends and relatives and often conceal abortion more frequently than other racial and ethnic groups (Shellenberg \& Tsui, 2012). It has also been reported that Protestant and Catholic women who described themselves as less religious or spiritual perceived less stigma for abortion than those who considered themselves more religious or spiritual (Cockrill et al., 2013).

However, most of the research on the subject has been undertaken in Western developed countries (Biggs et al., 2017; Fergusson et al., 2008; Rees \& Sabia, 2007; Pedersen, 2008; Taft \& Watson, 2008; National Collaborating Center for Mental Health, 2011; Munk-Olsen et al., 2011; Huang et al., 2012). These countries report the lowest number of abortions in the world (11.8\%), of which only $12.5 \%$ are unsafe, and abortion has been legal for decades. Conversely, in developing countries, $50 \%$ of all abortions performed are unsafe. In Latin America, six and a half million abortions are performed annually, $76.4 \%$ of which are unsafe (Ganatra, 2017). In Latin America, voluntary interruption of pregnancy has only been decriminalized in five countries: Cuba, Puerto Rico, Guyana, Uruguay, and French Guiana (Center for Reproductive Rights, 2018).

In Mexico, 30 out of 32 states punish women with prison sentences ranging from 15 days to six years for voluntarily interrupting a pregnancy. Some penal codes also consider sanctions such as psychiatric treatment and/ or community work (GIRE, 2018). The only place in the country where the voluntary termination of pregnancy during the first trimester is legal is Mexico City. Since 2007, following changes to the legislation, the Secretaría de Salud has implemented this procedure safely and at no cost for women (Mondragón y Kalb et al., 2011). It is therefore a space of possibility for conducting studies on the subject, particularly since despite the success of the Legal Interruption of Pregnancy (LIP) program, a social context continues to prevail in which motherhood is one of the most important values and women are stigmatized for having abortions (McMutrie et al., 2012; Sorhaindo et al., 2014). On the other hand, most studies on the issue in Mexico were conducted before abortion was decriminalized in Mexico City (Lafaurie et al., 2005; Erviti, Castro, \& Sánchez, 2006), or have been carried out at health service providers (Lamas, 2014) or on women who have not necessarily had an abortion (Sorhaindo et al., 2016).

For example, Sorhaindo et al. (2014) conducted a qualitative study on women who had interrupted their pregnancies in several Mexican cities and their partners to explore the sources, experiences, and consequences of abortion stigma. Respondents reported having felt pain, shame, sadness, and guilt related to abortion. They also admitted fearing divine punishment associated with the prohibition of abortion 
by the Catholic Church -such as becoming infertile-, which produced feelings of anxiety and exacerbated the guilt and shame of having had an abortion, especially if the family held these beliefs. In fact, they and their partners had chosen to conceal the experience for fear of being judged by their family and friends. However, younger women were proud of their ability to make decisions and to have successfully resolved a difficult situation, which made them feel privileged for having prioritized their health and personal well-being.

In view of the above, this study seeks to determine stigma levels in women who underwent a Legal Interruption of Pregnancy (LIP) at a clinic in Mexico City, and explore whether these levels are associated with any sociodemographic characteristic and whether there are any differences between those with and without high depressive symptomatology. As far as we know, this is the first effort in Mexico to address the issue from a perspective that includes mental health and within a public health paradigm that makes it possible to compare our findings with international results.

\section{METHOD}

\section{Design}

Cross-sectional exploratory study. Data were collected between December 2015 and January 2016 at a clinic where legal abortion services are provided in the public sector. A non-probabilistic, convenience sample was used.

\section{Participants}

Women over 15 years who underwent a LIP with medication and who, as part of the medical protocol, attended a follow-up consultation at a LIP clinic of the Mexico City's Secretaría de Salud.

\section{Instruments}

\section{Stigma over having aborted}

This was evaluated using six items from Cockrill et al. (2013) and two from Ralph et al. (2014) constructed and applied in the US. The eight Likert-type items had four possible answers: $0=$ not at all; $1=$ a little; $2=$ quite a bit; and $3=$ a lot. Higher values indicated higher stigma levels. Factor analysis revealed two factors; the Eigen value of the first one being 3.24 and 1.55 of the second. Together they explain $60 \%$ of the variance, with four items each and factor weights of over .58 . The reliability analysis with the eight items was $\infty=.786$. For the first factor, the consistency was $\infty=.769$ and for the second, it was $\infty=.764$.

The first factor was called Internalized Stigma (IS), which refers to the self-judgment for having made the deci- sion to terminate a pregnancy (In general, do you feel some kind of rejection of abortion for spiritual or religious reasons? Do you have a spiritual or religious conflict about your personal decision? How confident do you feel you made the right decision? And how calm do you feel about this decision? -These last two are graded inversely-). The second factor, Perceived Social Stigma (PSS) concerns what others might think and the negative consequences there would be if they knew that the woman had received an abortion (How much do you worry certain people could find out about this decision? How much would the interruption of the pregnancy negatively affect your relationship with someone you love? How much would others humiliate you if they found out about your decision? How worried are you that people would gossip about you if they found out about your decision?).

\section{Depressive symptoms}

The revised version of the Center for Epidemiological Studies of the Depression Scale (CES-DR) was used (González-Forteza et al., 2008). The CES-DR includes 35 questions with response options marked between 0 and 14 days. The internal consistency of the scale was $\infty=.940$ ). The cut-off point was set at the 75th percentile in order to classify the variable dichotomously and to consider the group scores as a reference given that there is no other measurement. Cases with high depressive symptomatology were selected.

\section{Procedure}

Women were approached in the waiting room of a LIP service of a Health Center during the schedule for follow-up medical appointments given as part of the medical care protocol. This appointment occurs at least one week after the LIP has been performed and consists of performing an ultrasound to ensure that the procedure has been completed and provide counseling for the use of post-event contraceptive methods.

The interview team explained the goals out loud to all the women present in the waiting room and invited them to participate in a study on women's mental and sexual health. Women interested in participating were addressed individually and told about the topics of the interview and the objectives of the project. If any of the women expressed interest in the invitation, they were read the informed consent form, and asked to sign it. Immediately afterwards, they were taken to a private area to answer the questionnaire.

The questionnaire was applied by a team of psychologists previously trained in both mental health and sexual and reproductive health issues. If at the end of the questionnaire the interviewer identified any mental distress or the re- 
spondent so requested, they were given general information and reference data on institutions that provide mental health care services in keeping with their problems, based on a previously designed and verified directory. Each respondent was given a 150 pesos supermarket coupon as compensation for the time of the interview.

\section{Data analysis}

In order to determine the association of sociodemographic characteristics and stigma, as well as the differences between those with and without depressive symptomatology, ANOVA and Student's T tests were performed. Moreover, in order to explore the factors associated with each type of stigma, two models of multiple linear regression were performed with sociodemographic variables and depressive symptomatology as explanatory variables. Data analysis was performed using STATA version 13.

\section{Ethical considerations}

The project was approved by the Ethics Committee of the Instituto Nacional de Psiquiatría Ramón de la Fuente Muñiz. Once the women had agreed to be interviewed, they signed an informed consent form and were reminded that their participation was voluntary and anonymous. Since this study involved minors, an appendix was included that was also approved by the Ethics Committee itself. This appendix concerned Rule 14 of the Council of International Organizations of Medical Sciences, which states that, in the case of married or pregnant minors, informed consent can be requested directly since they do not require the approval of an adult. Minors were also asked whether they gave their authorization to provide general information about the interview to the adult who accompanied them, if the latter so requested. This did not alter the principle of confidentiality. Only four respondents were under the age of 18 and none of their companions requested information.

\section{RESULTS}

\section{Sociodemographic characteristics}

Respondents had an average age of 24. The youngest was 15 and the oldest 44. Regarding educational attainment, $48.2 \%$ had completed high school and $24.6 \%$ had graduated from university. In terms of occupation, $51.8 \%$ were engaged in paid work. Of the total number of participants, $83.3 \%$ were partnered (Table 1). As for the place of residence, $62.3 \%$ lived in Mexico City, while $36 \%$ lived in the State of Mexico. Of the total, $66.7 \%$ had had a previous pregnancy, $78.5 \%$ had children, and $19.5 \%$ had previously had a voluntary abortion.
Table 1

Sociodemographic data on women who underwent a legal interruption of pregnancy $(n=114)$

\begin{tabular}{lcc}
\hline & $n$ & $\%$ \\
\hline Age & 16 & 14.0 \\
$15-19$ & 47 & 41.2 \\
$20-24$ & 25 & 21.9 \\
$25-29$ & 12 & 10.5 \\
$30-34$ & 14 & 12.3 \\
$35-44$ & & \\
Educational attainment & 31 & 27.2 \\
Middle school or less & 55 & 48.2 \\
High school or technical course & 28 & 24.6 \\
Bachelor's degree & & \\
Occupation & 59 & 51.8 \\
Employee & 29 & 25.4 \\
Student & 24 & 21.1 \\
Housewife & & \\
Do you currently have a partner? & 95 & 83.3 \\
Yes & 19 & 6.7 \\
No & & \\
Socioeconomic level & & \\
Lower class or poor & 61.3 \\
Middle class & 12 & 16.0 \\
Upper class & 2 & 2.7 \\
\hline
\end{tabular}

\section{Experiences and feelings on abortion}

An analysis of the frequencies of the eight items on the abortion stigma scale showed that $60.5 \%$ answered that they were very confident they had made the right decision and $49.1 \%$ said that they were very calm about their decision. Moreover, most women did not have spiritual or religious conflicts regarding their personal decision (to abort) $(67.5 \%)$ and did not reject abortion due to spiritual or religious issues $(65.8 \%)$. At the same time, 27.2\% were extremely concerned that certain people might find out about their abortion and $17.5 \%$ were seriously worried they might be humiliated for this reason.

\section{Types of stigma over having aborted and socio-demographic characteristics}

After adding up the answers and obtaining the average $(\operatorname{Min}=0, \operatorname{Max}=3)$, it was found that the overall stigma level was .8 (CI 95\% .7 - 1.0). Analyzing by dimension, the median internalized stigma was .6 (CI 95\% $=.5-.7)$, lower than the average perceived social stigma (average $=1.1$, CI $95 \% .9-1.2$ ). On the other hand, no statistically significant differences were found in internalized stigma levels or in the social stigma perceived by age, educational attainment, occupation, socioeconomic level and whether or not they were partnered (Table 2). 
Table 2

Stigma levels due to abortion according to sociodemographic characteristics of women who interrupted their pregnancy in Mexico City $(n=114)$

\begin{tabular}{|c|c|c|c|c|c|c|c|c|}
\hline & \multicolumn{4}{|c|}{ Internalized stigma } & \multicolumn{4}{|c|}{ Perceived social stigma } \\
\hline & Mean & $S D$ & ANOVA/t & $p$ & Mean & $S D$ & ANOVA/t & $p$ \\
\hline \multicolumn{9}{|l|}{ Age in years } \\
\hline 15 to 19 & .5 & .6 & $f=1.87$ & .12 & 1.3 & .9 & $f=1.04$ & .39 \\
\hline 20 to 24 & .7 & .6 & & & 1.1 & .8 & & \\
\hline 25 to 29 & .4 & .5 & & & .8 & .8 & & \\
\hline 30 to 34 & .5 & .9 & & & 1.3 & 1.0 & & \\
\hline 35 to 44 & .9 & 1.0 & & & 1.0 & .9 & & \\
\hline \multicolumn{9}{|l|}{ Educational attainment } \\
\hline Middle school or less & .6 & .7 & $f=2.05$ & .13 & .8 & .9 & $f=1.96$ & .15 \\
\hline High school or technical course & .7 & .7 & & & 1.1 & .8 & & \\
\hline Bachelor's Degree & .4 & .4 & & & 1.3 & .8 & & \\
\hline \multicolumn{9}{|l|}{ Occupation } \\
\hline Employee & .5 & .7 & $f=1.99$ & .14 & 1.1 & .9 & $f=.49$ & .61 \\
\hline Student & .7 & .5 & & & 1.2 & .8 & & \\
\hline Housewife & .8 & .7 & & & 1.0 & .9 & & \\
\hline \multicolumn{9}{|l|}{ Socioeconomic level } \\
\hline Lower class or poor & .6 & .7 & $f=.45$ & .64 & 1.0 & .9 & $f=1.35$ & .26 \\
\hline Middle class & .7 & .6 & & & 1.0 & .8 & & \\
\hline Upper class & .5 & .6 & & & 1.3 & .9 & & \\
\hline \multicolumn{9}{|l|}{ Do you currently have a partner? } \\
\hline Yes & .6 & .6 & $\mathrm{t}=.81$ & .42 & 1.1 & .9 & $t=.33$ & .74 \\
\hline No & .5 & .7 & & & 1.0 & .9 & & \\
\hline
\end{tabular}

\section{Stigma due to abortion and its association with depressive symptomatology}

Scores for internalized and socially perceived stigma are higher in women with high depressive symptomatology than those without it (Figure 1).

Lastly, multiple linear regression models, adjusted by sociodemographic variables (Table 3 ), indicate that the likelihood of scoring higher on internalized abortion

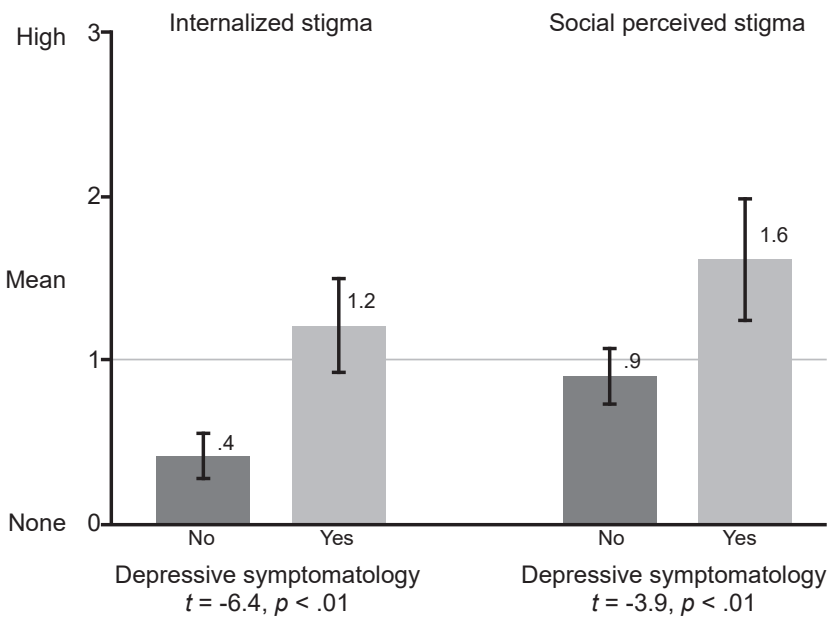

Figure 1. Stigma and depressive symptomatology. stigma $(\mathrm{r} 2=.36)($ coef. $=.77)$ and perceived social stigma $(\mathrm{r} 2=.24)($ coef. $=.80)$ is higher in those with high depressive symptomatology than in the group without this symptomatology.

\section{DISCUSSION AND CONCLUSION}

First of all, it is essential to mention that respondents reported low abortion stigma scores since, in a range of 0 to 3 , the overall average was $\mathrm{M}=.8$, a long way from the highest score on the scale. However, the average perception of being judged by others $(\mathrm{M}=1.1)$ was almost twice that of the self-perception of stigma $(M=.6)$. This indicates that women in this study did not show high self-stigmatization for having decided to have an abortion, but that they do tend to consider that abortion is socially unacceptable. Accordingly, they anticipate negative judgments from other people for having an abortion, as reported in other studies (Cockrill et al., 2013; Hanschmidt et al., 2016).

No differences were found in stigma levels due to sociodemographic variables, which shows that regardless of these characteristics, participants have similar levels of abortion stigma. Likewise, the sociodemographic information of the women interviewed in this study is similar to that reported by Mexico City's Secretaría de Salud (2018) with respect to the total number of women who have undergone 
Table 3

Factors associated with the types of abortion stigma in women who interrupted their pregnancy in Mexico City $(n=114)$

\begin{tabular}{|c|c|c|c|c|c|c|}
\hline & \multicolumn{3}{|c|}{ Internalized stigma } & \multicolumn{3}{|c|}{ Perceived social stigma } \\
\hline & Coef & $p$ & $\mathrm{Cl} 95 \%$ & Coef & $p$ & $\mathrm{Cl} 95 \%$ \\
\hline \multicolumn{7}{|l|}{ Age in years } \\
\hline 15 to 19 & 1.0 & & & 1.0 & & \\
\hline 20 to 24 & .17 & .35 & $-.19-.53$ & -.34 & .18 & $-.83-.15$ \\
\hline 25 to 29 & -.06 & .77 & $-.49-.36$ & -.61 & .05 & $-1.20--.02$ \\
\hline 30 to 34 & -.04 & .88 & $-.55-.47$ & -.27 & .46 & $-.98-.44$ \\
\hline 35 to 44 & .39 & .11 & $-.08-.87$ & -.38 & .25 & $-1.04-.27$ \\
\hline \multicolumn{7}{|l|}{ Educational attainment } \\
\hline Middle school or less & 1.0 & & & 1.0 & & \\
\hline High school or technical course & .14 & .36 & $-.16-.43$ & .24 & .24 & $-.16-.65$ \\
\hline Bachelor's Degree & .01 & .97 & $-.37-.38$ & .45 & .09 & $-.07-.97$ \\
\hline \multicolumn{7}{|l|}{ Occupation } \\
\hline Employee & 1.0 & & & 1.0 & & \\
\hline Student & .08 & .62 & $-.23-.39$ & -.17 & .43 & $-.60-.26$ \\
\hline Housewife & .08 & .60 & $-.22-.39$ & -.11 & .62 & $-.53-.32$ \\
\hline \multicolumn{7}{|l|}{ Socioeconomic level } \\
\hline Lower class or poor & 1.0 & & & 1.0 & & \\
\hline Middle class & .10 & .47 & $-.18-.38$ & -.04 & .85 & $-.43-.35$ \\
\hline Upper class & -.02 & .91 & $-.34-.30$ & .24 & .27 & $-.20-.68$ \\
\hline \multicolumn{7}{|l|}{ Do you currently have a partner? } \\
\hline Yes & 1.0 & & & 1.0 & & \\
\hline No & -.20 & .21 & $-.51-.12$ & -.12 & .58 & $-.56-.31$ \\
\hline \multicolumn{7}{|l|}{ Depressive symptomatology } \\
\hline No & 1.0 & & & 1.0 & & \\
\hline Yes & .77 & $<.01$ & $.52-1.02$ & .80 & $<.01$ & $.45-1.15$ \\
\hline
\end{tabular}

this procedure since 2007. The majority were young (between 20 and 29), with secondary and university education, and had at least one child.

Regarding depressive symptomatology, a statistically significant association was found with abortion stigma, particularly perceived social stigma. In this regard, it is important to clarify that, although results appear to show that the perception of stigma can negatively modify the experience of abortion (Rocca et al., 2015) and increase emotional distress, particularly depression (Kimport, Foster, \& Weitz, 2011; O'Donnell et al., 2018), a causal relationship between stigma and depressive symptomatology cannot be assumed.

On the other hand, most respondents do not have a spiritual or religious conflict over their decision to abort and feel at peace with themselves. This coincides with what Rocca et al. (2015) report that, despite the variety and complexity of the emotions experienced by women, one week after an abortion, nearly all of them felt that this was the right decision. Their findings indicate that, in fact, three years after the termination of their pregnancies, women who had had an abortion continued to report that they felt they had made the right decision (Rocca et al., 2015).
It is essential to mention that the results of this research project have the following limitations: only women who interrupted their pregnancies with medication under legal conditions during the first trimester of pregnancy in Mexico City were interviewed. At the same time, the size of the sample was small, the selection was not randomized, and was only moderately suitable (Lloret-Segura et al., 2014). Moreover, the fact that the women interviewed had already interrupted their pregnancies means that they are able to make fewer stigmatizing judgments about themselves and other women (Sorhaindo, 2014).

The results of this article are not sufficient to elucidate the directionality of the mechanisms of the association between abortion and depression. As already mentioned, the presence of depressive symptomatology after an abortion is influenced by several factors not considered in this article, such as mental health before pregnancy, exposure to adversity (Steinberg \& Tschann, 2013), or the decision to abort (Broen et al., 2005). Moreover, given that the interviews were conducted with the women a week after their abortions, this depressive symptomatology could indicate an adjustment reaction to a highly stressful process and may not be indicative of a possible mental disorder. Only if wom- 
en were monitored, would make it possible to determine whether symptoms persist over time (Flores Celis, 2016).

In order to strengthen the evidence, it would be necessary to increase the sample size and choose it probabilistically, which will also make it possible to test more complex hypotheses. Also, for future studies it is suggested that researchers work with contrasting samples or longitudinal designs. It is also suggested that women should be asked whose judgment worries them. Nonetheless, the findings of this article are among the first quantitative measurements made with Mexican women who have had a LIP performed and show a relationship between the variables in keeping with those reported by studies from other countries.

The idea that abortion brings about emotional problems and is a procedure women regret having is one of the fundamental components for promoting its criminalization. It is therefore important to consider evidence from studies such as this -which inquire directly about the experience of women when they interrupt a pregnancy- in the design and implementation of public policies and legislation in this regard.

Participants in this study were more concerned about what others might think about their decision to terminate a pregnancy and how abortion could affect their relationship with them. These concerns highlight the need to reduce the negative social stigma surrounding abortion. In this respect, ensuring that women feel less stigmatized for interrupting a pregnancy as well as improving the perception of self-efficacy and self-care could influence the decrease in the emotional burden women traditionally face when making decisions about their sexual and reproductive health (Kimport, Foster, \& Weitz, 2011).

Legislation is essential but not sufficient to make sexual and reproductive health services accessible to all women or to prevent unsafe abortion (Becker \& Díaz Olavarrieta, 2013). Social determinants, cultural biases, and barriers to access health services continue to constitute an obstacle for women. In fact, many women probably do not even know about the legislation or consider a LIP an option in the event of an unwanted pregnancy (Becker \& Díaz Olavarrieta, 2013).

This study represents a first quantitative approach to the population of women who legally abort from a mental health research framework, which paves the way for new lines in a context in which abortion is still criminalized throughout the country with exception of Mexico City. The authors recognize its limitations and the need to continue exploring the subject, particularly to more accurately determine the aspects currently being discussed in the international debate, while considering the Latin American perspective and specifically the Mexican one. Lastly, it is useful to continue researching the role of internalized and social stigma, together with other relevant factors, on mechanisms that increase emotional distress and jeopardize women's mental health.

\section{Funding}

Supermarket coupons awarded to the participants were financed by Ipas, Mexico.

\section{Conflicts of interests}

The authors declare that they have no conflict of interest.

\section{Acknowledgements}

The authors are grateful to the women interviewed who contributed to this study with their participation, as well as Dr. Patricio Sanhueza of the SEDESA Sexual and Reproductive Health Program, and the staff of the clinic where the study was conducted for the facilities granted during the project.

\section{REFERENCES}

Becker, D. \& Díaz Olavarrieta, C. (2013). Decriminalization of abortion in Mexico City: the effects on women's reproductive rights. American Journal of Public Health, 103(4), 590-593. doi: 10.2105/AJPH.2012.301202

Biggs, M. A., Upadhyay, U. D., McCulloch, C. E., \& Foster, D. G. (2017). Women's mental health and well-being 5 years after receiving or being denied an abortion: A prospective, longitudinal cohort study. JAMA psychiatry, 74(2), 169-178. doi: 10.1001/jamapsychiatry.2016.3478

Broen, A., Moum, T., Bødtker, A., \& Ekeberg, Ø. (2005). The course of mental health after miscarriage and induced abortion: a longitudinal, five-year follow-up study. BMC medicine, 3(1), 1. doi: 10.1186/1741-7015-3-18

Centre for Reproductive Rights. (2018). The World's abortion laws 2018. Retrieved from: http://worldabortionlaws.com

Cockrill, K. \& Hessini, L. (2014). Introduction: Bringing Abortion Stigma into Focus. Women \& Health, 54(7), 593-598. doi: 10.1080/03630242.2014.947218

Cockrill, K., Upadhyay, U., Turan, J. \& Greene Foster, D. (2013). The stigma of having an abortion: development of a scale and characteristics of women experiencing abortion stigma. Perspectives on Sexual and Reproductive Health, 45(2), 79-88. doi: 10.1363/4507913

Erviti, J., Castro, R., \& Sánchez, I. A. S. (2006). Las luchas clasificatorias en torno al aborto: el caso de los médicos en hospitales públicos de México. Estudios sociológicos, 24(72), 637-665.

Fergusson, D. M., Horwood, L. J., \& Boden, J. M. (2008). Abortion and mental health disorders: evidence from a 30-year longitudinal study. The British Journal of Psychiatry, 193(6), 444-451. doi: 10.1192/bjp.bp.108.056499

Flores Celis, K. (2016). Las emociones y sintomatología depresiva en mujeres que interrumpen el embarazo en la Ciudad de México. Master's thesis. Universidad Nacional Autónoma de México.

Ganatra, B., Gerdts, C., Rossier, C., Johnson Jr, B. R., Tunçalp, Ö., Assifi, A., ... \& Bearak, J. (2017). Global, regional, and subregional classification of abortions by safety, 2010-14: estimates from a Bayesian hierarchical model. The Lancet, 390(10110), 2372-2381. doi: 10.1016/S0140-6736(17)31794-4

González-Forteza, C., Ramos, L., Jiménez, A., \& Wagner, F. A. (2008). Aplicación de la escala de Depresión del Center of Epidemiological Studies en adolescentes de la Ciudad de México. Salud Pública de México, 50(4), 292-299. doi: 10.1590/ S0036-36342008000400007

Grupo de Información en Reproducción Elegida (GIRE). (2018). Plataforma de consultas: causales de aborto en códigos penales estatales. Mexico City.

Hanschmidt, F., Linde, K., Hilbert, A., Riedel-Heller, S. G., \& Kersting, A. (2016). Abortion Stigma: A Systematic Review. Perspectives on Sexual and Reproductive Health, 48(4), 169-177. doi: 10.1363/48e8516

Huang, Z., Hao, J., Su, P., Huang, K., Xing, X., Cheng, D., ... \& Tao, F. (2012). The impact of prior abortion on anxiety and depression symptoms during a subsequent pregnancy: data from a population-based cohort study in China. Klinik Psikofarmakoloji Bülteni-Bulletin of Clinical Psychopharmacology, 22(1), 51-58. doi: 10.5455/bcp.20111102040509 
Kimport, K., Foster, K., \& Weitz, T. A. (2011). Social sources of women's emotional difficulty after abortion: lessons from women's abortion narratives. Perspectives on sexual and reproductive health, 43(2), 103-109. doi: 10.1363/4310311

Kumar, A., Hessini, L., \& Mitchell, E. M. (2009). Conceptualizing abortion stigma. Culture, Health \& Sexuality, 11(6), 625-639. doi: 10.1080/13691050902842741

Lafaurie, M. M., Grossman, D., Troncoso, E., Billings, D., Chávez Alvarado, S., Maira, G., Martínez, I., Mora, M., \& Ortiz, O. (2005). El aborto con medicamentos en América latina: Las experiencias de las mujeres en México, Colombia, Ecuador y Perú. Mexico: Population Council.

Lamas, M. (2014). Entre el estigma y la ley: La interrupción legal del embarazo en el DF. Salud Pública de México, 56(1), 56-62.

Lerner, S., Guillaume, A., \& Melgar, L. (2016). Realidades y falacias en torno al aborto: salud y derechos humanos. El Colegio de México AC.

LeTourneau, K. \& Tyson, H. (2016). Combatiendo el estigma. La red internacional para la reducción de la discriminación y el estigma en torno al aborto: INROADS. Retrieved from: http://clacaidigital.info/handle/123456789/916

Lloret-Segura, S., Ferreres-Traver, A., Hernández-Baeza, A., \& Tomás-Marco, I. (2014). El análisis factorial exploratorio de los ítems: una guía práctica, revisada y actualizada. Anales de psicología, 30(3), 1151-1169. doi: 10.6018/ analesps.30.3.199361

Major, B., Appelbaum, M., Beckman, L., Dutton, M. A., Russo, N. F., \& West, C. (2009). Abortion and mental health: Evaluating the evidence. American Psychologist, 64(9), 863-890. doi: 10.1037/a0017497

McMurtrie, S. M., García, S. G., Wilson, K. S., Diaz-Olavarrieta, C., \& Fawcett, G. M. (2012). Public opinion about abortion-related stigma among Mexican Catholics and implications for unsafe abortion. International Journal of Gynecology \& Obstetrics, 118(S2), S160-S166. doi: 10.1016/S0020-7292(12)60016-2

Mondragón y Kalb, M., Ahued Ortega, A., Morales Velazquez, J., Díaz Olavarrieta, C., Valencia Rodríguez, J., Becker, D., \& García, S. G. (2011). Patient characteristics and service trends following abortion legalization in Mexico City, 2007-10. Studies in family planning, 42(3), 159-166. doi: 10.1111/j.17284465.2011.00277.x

Munk-Olsen, T., Laursen, T. M., Pedersen, C. B., Lidegaard, Ø., \& Mortensen, P. B. (2011). Induced first-trimester abortion and risk of mental disorder. New England Journal of Medicine, 364(4), 332-339. doi: 10.1056/NEJMoa0905882

National Collaborating Centre for Mental Health. (2011). Induced abortion and mental health: A systematic review of the mental health outcomes of induced abortion, including their prevalence and associated factors. London: Academy of Medical Royal Colleges.

O’Donnell, A. T., O'Carroll, T., \& Toole, N. (2018). Internalized stigma and stigma-related isolation predict women's psychological distress and physical health symptoms post-abortion. Psychology of Women Quarterly. doi: $10.1177 / 0361684317748937$

Pedersen, W. (2008). Abortion and depression: a population-based longitudinal study of young women. Scandinavian Journal of Public Health, 36(4), 424-428. doi: $10.1177 / 1403494807088449$
Ralph, L., Gould, H., Baker, A., \& Foster, D. G. (2014). The role of parents and partners in minors' decisions to have an abortion and anticipated coping after abortion. Journal of Adolescent Health, 54(4): 428-434. doi: 10.1016/j. jadohealth.2013.09.021

Rees, D. I. \& Sabia, J. J. (2007). The relationship between abortion and depression: new evidence from the fragile families and child wellbeing study. Medical Science Monitor, 13(10), CR430-CR436. PMID: 17901849

Robinson, G. E., Stotland, N. L., Russo, N. F., Lang, J. A., \& Occhiogrosso, M. (2009). Is there an "abortion trauma syndrome"? Critiquing the evidence. Harvard Review of Psychiatry, 17(4), 268-290. doi: 10.1080/10673220903149119

Rocca, C. H., Kimport, K., Roberts, S. C., Gould, H., Neuhaus, J., \& Foster, D. G. (2015). Decision rightness and emotional responses to abortion in the United States: A longitudinal study. PLoS One, 10(7), e0128832. doi: 10.1371/journal. pone. 0128832

Russo, N. F. (2014). Abortion, unwanted childbearing, and mental health. Salud Mental, 37(4), 283-291.

Secretaría de Salud de la Ciudad de México. (2018). Estadísticas Abril de $2007-$ Agosto de 2018. Retrieved from: http://ile.salud.cdmx.gob.mx/wp-content/ uploads/Interrupcion-Legal-del-Embarazo-Estadisticas-2007-2017-20-de-abrilde-2017.pdf

Shellenberg, K. M. \& Tsui, A. O. (2012). Correlates of perceived and internalized stigma among abortion patients in the USA: an exploration by race and Hispanic ethnicity. Int $J$ Gynaecol Obstet., 118(Suppl 2), 152-9. doi: 10.1016/S00207292(12)60015-0

Sorhaindo, A. M., Juárez-Ramírez, C., Olavarrieta, C. D., Aldaz, E., Mejía Piñeros, M. C., \& Garcia, S. (2014). Qualitative evidence on abortion stigma from Mexico City and five states in Mexico. Women \& Health, 54(7), 622-640. doi: 10.1080/03630242.2014.919983

Sorhaindo, A. M., Karver, T. S., Karver, J. G., \& Garcia, S. G. (2016). Constructing a validated scale to measure community-level abortion stigma in Mexico. Contraception, 93(5): 421-431. doi: 10.1016/j.contraception.2016.01.013

Steinberg, J. R. \& Tschann, J. M. (2013). Childhood adversities and subsequent risk of one or multiple abortions. Social Science \& Medicine, 81, 53-59. doi: 10.1016/j.socscimed.2012.11.011

Steinberg, J. R., Tschann, J. M., Furgerson, D., \& Harper, C. C. (2016). Psychosocial factors and pre-abortion psychological health: The significance of stigma. Social Science \& Medicine, 150: 67-75. doi: 10.1016/j.socscimed.2015.12.007

Taft, A. J. \& Watson, L. F. (2008). Depression and termination of pregnancy (induced abortion) in a national cohort of young Australian women: the confounding effect of women's experience of violence. BMC Public Health, 8(1), 75. doi: 10.1186/1471-2458-8-75

Vigneta. E., Polis, C. B., Sridhara, S. K., \& Blum, R. W. (2008). Abortion and long-term mental health outcomes: a systematic review of the evidence. Contraception, 78(6), 436-450. doi: 10.1016/j.contraception.2008.07.005 